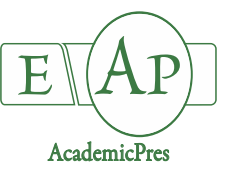

Shahrajabian MH et al. (2020)
Notulae Botanicae Horti Agrobotanici Cluj-Napoca 48(4):1719-1741
DOI: $10.15835 /$ nbha48412002
Review Article

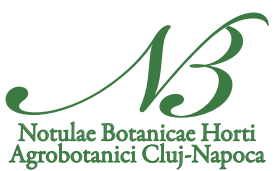

\title{
Exploring Artemisia annua L., artemisinin and its derivatives, from traditional Chinese wonder medicinal science
}

\section{Mohamad H. SHAHRAJABIAN ${ }^{\text {la }}$, Wenli SUN ${ }^{\text {lb }}$, Qi CHENG ${ }^{1,2 *}$}

\author{
${ }^{I}$ Chinese Academy of Agricultural Sciences, Biotechnology Research Institute, Beijing 100081, \\ China; hesamshahrajabian@gmail.com; sunwenli@caas.cn \\ ${ }^{2}$ Hebei Agricultural University, College of Life Sciences, Baoding, Global Alliance of HeBAU-CLS\&HeQiS for BioAl- \\ Manufacturing,Baoding, Hebei 071000,China; chengqi@caas.cn (*corresponding author) \\ ${ }^{a, b}$ These authors contributed equally to the work
}

\begin{abstract}
Artemisia annua L. (Chinese wormwood herb, Asteraceae) synthesizes artemisinin, which is known as qinghaosu, considers as a unique sesquiterpene endoperoxide lactone. In traditional Chinese medicine, it has been used for the treatment of fevers and haemorrhoides. More researches on Artemisia annua L. and its derivatives, especially artemisinin and other metabolites will help to increase the knowledge and value of $A$. annua and its constituents. Phenolics from Artemisia annua consists of coumarins, flavones, flavonols, phenolic acids, and miscellaneous. Artemisinin has attracted much attention from scientists due to its potent antimalarial properties as secondary metabolites. Moreover, more attentions are focusing on the roles of artemisinin and its derivatives in treating obesity and metabolic diseases. They also have anti-bacterial, antiinflammatory, anti-tumor, anti-protozoa, anti-helminthic, anti-fungal, anti-angiogenic and antiproliferation properties. The most important derivatives of Artemisia annua L. are arteether, artemether, artemiside, artemisinin, artemisone, artesunate, and dihydroartemisinin. Artemisinin also use against some cancers such as liver cancer, brain glioma, leukemia, nasopharyngeal cancer, gallbladder cancer, gastric cancer, cervical cancer, lung cancer, breast cancer and colon cancer. This important gift from ancient Chinese traditional medicine can guarantee health of people all around the world. Further researches should be done on the new advances and development of artemisinin and its derivatives as potential natural medicine in the global fight against so many diseases, malaria included.
\end{abstract}

Keywords: artemisia; artemisinin; cancer; Chinese medicine; malaria

\section{Introduction}

For thousand years, the most commonly treatment which has been widely used in different parts of the world, especially Asia was traditional herbal medicines (Shahrajabian et al., 2020a, b; Sun et al., 2020a, b), because of containing various ranges of chemical contents with different pharmacological applications. They are used by people because of effectiveness, frequently inadequate provision of modern medicine, cultural beliefs and preferences (Sun et al., 2019a, b; Shahrajabian et al., 2020c, d). Artemisia annua L., Asteraceae, has diverse biological actions from anticancer to anti-malarial activities (Beekman et al., 1998) with high 
antioxidant activities from its leaves because of the high content of flavonoids (Zheng and Wang, 2001; Bilia et al., 2006). The goal of this manuscript is review of Artemisia annua and its derivatives with considering tremendous health benefits.

Artemisia annua L. an ancient herb in traditional Chinese medicine to modern drug

One of the most important branches of traditional medicine is traditional Chinese medicine with more than 3500 years medical practices (Shahrajabian et al., 2019a, b, c, d). Malaria affects more than 200 million people in many African and Asian countries ( $\mathrm{NaB}$ and Efferth, 2019). Artemisia is the largest genus in the tribe Anthemideae of the Asteraceae family consisting of more than 500 species (Lim et al., 2018; Li et al., 2020; Lu et al., 2020). The most important species of Artemisia are $A$. absinthium, $A$. abrotanum, $A$. afra, $A$ annua, $A$. arborescens, $A$. asiatica, $A$. capillaries, A. campestris, A. douglasiana, $A$. dracunculus, $A$. judaica, $A$. maritime, A. mogoltavica, A. monospermal, A. nilagirica, A. scoparia, A. tripartite, A. verlotorum, $A$. vestita, and $A$. vulgaris (Bora and Sharma, 2011). The content of Artemisia annua L. is artemisinin, which is a member of the Artemisia family which has been used in traditional Chinese medicine for thousand years (Njuguna et al., 2012; $\mathrm{Tu}, 2016)$. It is a typical short-day photoperiod (Lv et al., 2018). It has appeared in many ancient Chinese medical manuscripts, which describe its uses to include treatment of wounds, alleviating intermittent fevers, as well as enhancing the brightness of eyes and even improving longevity (Liu et al., 2013). In traditional Chinese medicine, it used to treat fever, chill and an ancient Chinese herbal remedy for pyrexia (Abba et al., 2018). It is called sweet wormwood, Chinese wormwood, Sweet Annie in English; Absinthe chinoise, armoise annuelle in French; Qinghao, Cao hao, Cao Qinghao, Cao Haozi, Chou Qinghao, Haoz, Kuhao, Xianghao, Xiang Qinghao and Xihehao in Chinese; Kusoninijin in Japanese, Than Hao and Than Cao Hoa Vang in Vietnamese, Chui Ho, Hwang-Hwa-Ho and Gae-Tong-Sok in Korean. The growing period of Artemisia annua from seedling until harvest is 190-240 days, depending on the climate and altitude of the production area. Artemisinin also known as Qinghaosu, and of over 2000 types of traditional Chinese herbs that were investigated, Artemisia annua (Sweet Annie, or Sweet Wormwood) exhibited significant inhibitory properties against malaria parasites (Lu et al., 2019). Artemisia L. is a genus of small herbs and shrubs, belonging to an important family Asteraceae (Salehi et al., 2018), which are mainly found in Asia, North America and Europe (Bora and Sharma, 2011).Its molecular formula is $\mathrm{C} 15 \mathrm{H} 22 \mathrm{O} 5$ and molecular mass $282.332 \mathrm{~g} / \mathrm{mol}$. El-Naggar et al. (2013) reported that Qinghao (Artemisia annua L.) is among the top 10 pharmaceutical crops which are receiving intensive worldwide scientific attention as it is currently only source for pharmaceutical production of artemisinin. The most important provinces under cultivation of $A$. annua $\mathrm{L}$. in China are Chongqing, Hunan, Hubei and Guizhou (Huang et al., 2010).

Scientific classification

Kingdom: Plantae

Division: Magnoliophyta

Class: Magnoliopsida

Order: Asterales

Family: Asteraceae

Genus: Artemisia

Species: $A$. annua

There are now many large $A$. annua L. plantations, which produce about $80 \%$ of Chinese artemisinin, in Chongqing, Southwest China (Zeng et al., 2018). The malaria drug artemisinin is an example of doing researches for many years on $A$. annua, a Chinese medicinal plant (Qinghao), which is known as sweet worm (Ikram and Simonsen, 2017). It is believed to have been first described by the Chinese during the Jin dynasty around 317-420 AD due to its medicinal properties specifically for reducing fever (Konstat-Korzenny et al., 2018). The artemisinin content of wild $A$. annua L. has been described to vary between $0.02 \%$ and $1.1 \%$ of the dry weight, depending on plant source and cultivation conditions (Delabays et al., 2001). Atremisinin isolated from the traditional Chinese herb Artemisia annua serves as a precursor to today's most effective antimalarial 
drugs against strains of Plasmodium falciparum parasites (Meshnick et al., 1996). Wild or cultivated $A$. annua $\mathrm{L}$. is a major source for artemisinin because chemical and biological synthesis of artemisinin is still under development due to poor yields (Huang et al., 2010). Tu was awarded her Nobel Prize in Physiology or Medicine in 2015 for the discovery of this important antimalarial compound as a head of a scientific group in 1967-1969 (Salehi et al., 2018). Artemisinins are a family of sesquiterpene trioxane lactone bearing an endoperoxide bridge, and used artemisinins includes artemisinin (ART), artesunate (AS), artemether (AM), arteether (AE) and dihydro-artemisinin (DHA) (Asano and Iwahashi, 2017; Shi et al., 2018). Artemisinin and its derivatives are powerful and important medicine because of their ability to swiftly reduce the number of Plasmodium parasites in the blood of patients affected by malaria (Negi et al., 2018; Lv et al., 2019). However, Phyo et al., (2018) noted that reliable efficacy of artesunate for the treatment of severe malaria may no longer be assured in areas where artemisinin resistance has emerged. Rath et al. (2004) stated that one liter of an aqueous preparation of nine grams of Artemisia annua contained 94.5 milligrams of artemisinin, which is approximately $19 \%$ of the usually recommended daily dose. It can grow easily in the humid tropics though the artemisinin yield appears to be affected significantly by several factors such as seed origin, planting season, soil moisture availability and cultivation methods (Brisibe et al., 2012). Moderate salt stress has been proved to increase the artemisinin synthesis by the plant (Correa-Ferreira et al., 2019).

\section{Phenolic constituents of Artemisia annua L. and Artemisinin biosynthetic pathways in A. annua}

Flavonoids, coumaris, steroids, phenolics, purines, lipids, aliphatic compounds, monoterpenoids, triterpenoids and sesquiterpenoids such as artemisnin have been isolated from the leaves and flower of $A$. annua (Bhakuni et al., 2001). Phenolics from Artemisia annua consists of coumarins, flavones, flavonols, phenolic acids, and miscellaneous. Coumarins included coumarin, aesculetin, iso-fraxidin, scopoletin, scopolin and tomentin. Flavones consiss of apigenin, luteolin, luteolin-7-methyl ether, acacetin, chrysoeriol, chrysin, cirsilineol, cirsiliol, cynaroside, eupatorin, cirsimaritin. Flavonols consist of artemetin, chrysosplenol C, chrysosplenol D, mikanin, astragalin, axillarin, casticin, eupatin, kaempferol, kaempferol-6-methoxy glucoside, tamarixetin, myricetin, gossypetin-3,-dimethyl ether, laricitrin, mearnsetin, quercetin, quercetin-3-glucoside, quercetin-3-methyl ether, quercimeritin, retusin, rhamnetin, isorhamnetin, rutin, mearnsetin-glucoside, chrysosplenetin, 3,5-Dihydroxy-3',4',6,7, tetra-methoxyflavone, Syringetin, Isokaempferide and Quercetagetin 3,4'-dimethyl-ether. Phenolic acids are chlorogenic acid, quinic acid and coumaric acid. Miscellaneous consist of 2,4-Dihydroxy-6 methoxy-acetophenone, 5-Nonadecy-3-O methyl ether- recorcinol, 2,2,6-trihydroxy chromene and 2,2-didhyroxy-6- methoxy-chromene (Hethelyi et al., 1995; Shatar et al., 2003; Rao et al., 2014; Lohani et al., 2016). Artemisia ketone, 1, 8-cineole and camphor are major essential oil composition of $A$. annua L. (Jain et al., 2002; Mukhtar et al., 2007; Goel et al., 2008; Liu et al., 2019). Other major chemical composition of the volatile oil from its seeds are Trans-3(10)-caren-4-ol, and $\delta$-selinene (Malik et al., 2009; Habibi et al., 2013). Libbey and Sturtz (1989) reported that the major components of the essential oil of $A$. annua $L$. was Artemisia ketone (35.7\%), 1,8-cineole (31.5\%), alpha-pinene (11.2\%), Artemisia alcohol (5.2\%) and myrcene (4.6\%). Charles et al. (1991) reported that the major components of the oil in leaves are Artemisia ketone (35.6\%), and 1,8-cineole (28.1\%) at the early summer harvested plants, artemisia ketone (26.8\%) and camphor (20.5\%) in leaves of fall harvested plants, and artemisia ketone (56\%), and camphor (10.5\%) in flowers of fall harvested plants. Ma et al. (2007) reported that terpene compounds are the main components of Artemisia annua L. Kazemi (2015) observed $\alpha$-pinene (7.33\%), camphene (5.68\%), sabinene (4.78\%), $\beta$-myrcene (22.41\%), 1,8-cineole (17.17\%) and camphor (20.41\%) as major constituents of Artemisia annua L. in Iran. Molecular structures of several common artemisinin monomers are shown in Figure 1. 


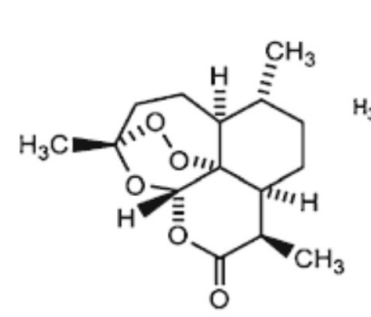

artemisinin

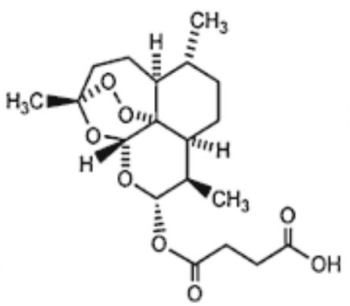

artesunate

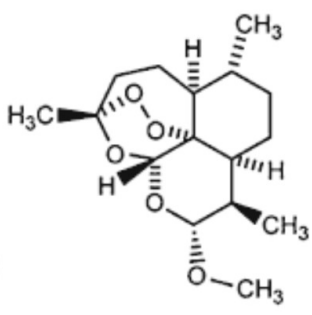

artemether

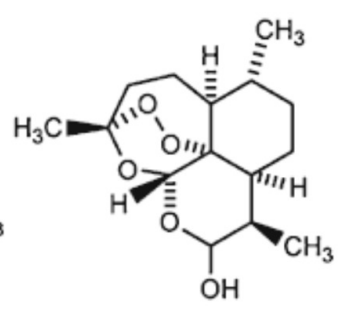

dihydroartemisinin

Figure 1. Molecular structures of several common artemisinin monomers (Lai et al., 2013)

\section{Artemisinin and its derivatives}

Artemisinin is a sesquiterpene lactone, an antimalarial substance, is obtained on large scale from dried leaves of Artemisia annua L. (Usuda et al., 2000; Widmer et al., 2007; Sulsen et al., 2011; Kumar et al., 2013). The biosynthesis of artemisinin was reported in the shoot cultures and genetically modified roots (hairy roots) of $A$. annua (Ram et al., 2014). Its derivatives such as artesunate, dihydroartemisinin and artemether are the most potential antimalarials available, rapidly killing all asexual stages of the parasite Plasmodium flaciparum (O' Neill, 2005). Fu et al. (2016) concluded that both plant height and stem bottom diameter had the most important positive impact on artemisinin content of the leaves and herb yield. Artemether is the methylated derivatives of artemisinin.

Artemether showed anti-parasitic properties toward many protozoan parasites such as Leishmania, Toxoplasma gondii and Trypansoma spp. (Mishina et al., 2007), and also a promising drug in control of schistosomiasis mansoni due to its reductive impact on worm burden and its role in improvement of hepatic granulomatous lesions (Madbouly et al., 2015). Production of artemisinin in genetically modified microorganisms is an attractive way to enable sufficient supply of the effective antimalarial agent (Zeng et al., 2012). It can be extracted using ultrasound-assisted extraction (UAE) and then detected via HPLC (Widmer et al., 2007; Wang and Liu, 2012; Zhang et al., 2014). The biosynthetic pathway of artemisinin belongs to the isoprenoid pathway and its production pathway was divided in two stages: in the first step Acetyl-CoA make isopentenyl diphosphate (IPP) and its isomer, dimethylallyl diphosphate; in the next step IPP produces artemisinin (Mirzaee et al., 2016). There are four enzymes, namely ADS, CYP71AV1, DBR2 and ALDH1 in artemisinin biosynthetic pathway, and the artemisinin content was determined by the chemo-type of CYP71AV1 (Lv et al., 2017), and the highly active CYP71AV1 is decided by an amino acid residue (Ser479) (Komori et al., 2013). Artemisinin derivatives are effective against other parasites such as Toxoplasma gondii (De Oliveira et al., 2009), Trypanosoma cruzi (Sulsen et al., 2008), Schistosoma japonicum, Schistosoma mansoni, Fasciola hepatica, and Clonorchis sinensis (Fathy, 2011), and Acanthamoebaspp. (Derda et al.2016). Lai et al. (2005) discovered that artemisinin and artemisinin-tagged iron-carrying compounds could be developed into powerful anticancer drugs. Njuguna et al. (2012) stated that artemisinin and its derivatives have revealed its potential use in treating other infectious and noninfectious diseases. Ivanescu et al. (2011) found artemisinin content in Romanian $A$. annua wild plants varies between 0.17 and $0.21 \%$ dry weight basis. Artemisinin, artesunate and artemether are well-tolerated in both children and adults, with no evidence of serious clinical toxicity (Price, 2000). Artemether-lumefantrine is the most widely used artemisinin-based combination therapy for malaria (Christian et al., 2017). Wojtkowiak-Giera et al. (2018) observed that $A$. annua extract is a natural substance which is well tolerated in animals and may be considered as a combination therapy in treatment of acanthamoebiasis. Artesunate is the most versatile derivative of artemisinin, because it is easily soluble in water, which has facilitated the development of oral and rectal formulas (Angus et al., 2002); it is an antimalarial agent and acts cytotoxically on tumor cells (Aquino et al., 2011; Kannan et al., 2019). Artseunate is not only an effective drug for treating tumor, but also it has been used for curing malaria, improving inflammation and protecting nerves (Noubiap, 2014; Bigoniya et al., 2015; Zhao et al., 2017; Gugliandolo et al., 2018; Wen et al., 2018). Kong et al. (2019) demonstrated that artesunate targeted activating 
hepatic stellate cells ferroptosis, and its effect was associated with activation of ferritinophagy. Phenolics compounds from Artemisia annua is shown in Table 1.

Table 1. Phenolics from Artemisia annua (Ferreira et al., 2010)

\begin{tabular}{|c|c|c|}
\hline Coumarins & $1-$ & Coumarin \\
\hline & $2-$ & Aesculetin \\
\hline & 3- & Iso-Fraxidin \\
\hline & 4- & Scopoletin \\
\hline & $5-$ & Scopolin \\
\hline & 6- & Tomentin \\
\hline \multirow[t]{11}{*}{ Flavones } & $7-$ & Apigenin \\
\hline & $8-$ & Luteolin \\
\hline & 9- & Luteolin-7-methyl ether \\
\hline & $10-$ & Acacetin \\
\hline & $11-$ & Chrysoeriol \\
\hline & $12-$ & Chrysin \\
\hline & 13- & Cirsilineol \\
\hline & $14-$ & Cirsiliol \\
\hline & $15-$ & Cynaroside \\
\hline & $16-$ & Eupatorin \\
\hline & $17-$ & Cirsimaritin \\
\hline \multirow[t]{28}{*}{ Flavonols } & $18-$ & Artemetin \\
\hline & $19-$ & Chrysosplenol C \\
\hline & $20-$ & Chrysosplenol D \\
\hline & $21-$ & Mikanin \\
\hline & $22-$ & Astragalin \\
\hline & $23-$ & Axillarin \\
\hline & $24-$ & Casticin \\
\hline & $25-$ & Eupatin \\
\hline & $26-$ & Kaempferol \\
\hline & $27-$ & Kaempferol-6-methoxy glucoside \\
\hline & $28-$ & Tamarixetin \\
\hline & $29-$ & Myricetin \\
\hline & $30-$ & Gossypetin-3,-dimethyl ether \\
\hline & $31-$ & Laricitrin \\
\hline & $32-$ & Mearnsetin \\
\hline & $33-$ & Quercetin \\
\hline & $34-$ & Quercetin-3-glucoside \\
\hline & $35-$ & Quercetin-3-methyl ether \\
\hline & $36-$ & Quercimeritrin \\
\hline & $37-$ & Retusin \\
\hline & $38-$ & Rhamnetin \\
\hline & $39-$ & Isorhamnetin \\
\hline & $40-$ & Rutin \\
\hline & $41-$ & Mearnsetin-glucoside \\
\hline & $42-$ & Chrysosplenetin \\
\hline & $43-$ & 3,5-Dihydroxy-3', $4^{\prime}, 6,7$, tetra-methoxyflavone \\
\hline & $44-$ & Syringetin \\
\hline & $45-$ & Isokaempferide \\
\hline
\end{tabular}


Shahrajabian MH et al. (2020). Not Bot Horti Agrobo 48(4):1719-1741

\begin{tabular}{|c|ll|}
\hline & $46-$ & Quercetagetin 3,4'-dimethyl-ether \\
\hline & \multicolumn{2}{|c|}{} \\
\hline & $47-$ & Chlorogenic acid \\
\hline Phenolic acids & $48-\quad$ Quinic acid \\
\hline & $49-\quad$ Coumaric acid \\
\hline & \\
\hline Miscellaneous & $50-$ & 2,4-Dihydroxy-6 methoxy-acetophenone \\
\hline & $51-$ & 5-Nonadecy-3-O methyl ether- recorcinol \\
\hline & $52-$ & 2,2,6-trihydroxy chromene \\
\hline & $53-$ & 2,2-didhyroxy-6- methoxy-chromene \\
\hline
\end{tabular}

From plant to medicine, the most important pharmacological properties of artemisinin and its derivatives

Artemisinin family drugs regulate innate immune cells, regulate adaptive immune cells, and it has efficacy in treating autoimmune diseases (Hou and Huang, 2016; Shen et al., 2018). Daddy et al. (2017) suggested the use of Artemisia annua dried leaf tablets to treat resistant malaria in which the synergic role of other components with artemisinin is claimed to tackle plasmodium resistance. The most important pharmacological effects of artemisinins consist of anti-virus, anti-cancer, anti-inflammatory and anti-oxidant (Ho et al., 2014; Shi et al., 2015). Lam et al. (2018) found that Artemisinin (ART) and its derivatives are potentially effective drugs for treating various helminthic diseases of public health significance. It has been reported that ART derivatives and synthetic peroxides such as ozonides and trioxolanes maybe used as alternative or complementary drugs against schistosomes (Keiser et al., 2012; Xiao et al., 2012). Moreover, ART and its derivatives also have activities against nematodes and cestodes (Kuster et al., 2014; Abou Rayia et al., 2017). Magoulas et al. (2017) suggested that artemisinin dimmers are good candidates for the development of effective anticancer agents. Shi et al. (2018) suggested that artemisinins are capable to treat neuroinflammation-related central nerve system (CNS) diseases in both direct and indirect manners. Qiang et al. (2018) provides direct evidence for the potential application of artemisinin B in the treatment of neuroinflammatory diseases. Wu et al. (2016) described the novel artemisinin derivatives in the treatment of autoimmune diseases. Lai et al. (2013) reported that artemisinin dimmers and trimers, artemisinin hybrid compounds, and tagging of aretemisnin compounds are involved in the intracellular iron-delivery mechanism, and all these compounds are promising potent anticancer compounds which may produce significantly less side effect than traditional chemotherapeutic agents. Zhao et al. (2017) noted that artemisinin enhances the stability of liver cell membrane, and reduce the damage of liver cell membrane and liver cell; it also showed a protective effect against chronic alcohol poisoning and incredible clinical potential to treat the liver injury induced by alcohol. Abba et al. (2018) also indicated that artemisinin-type drugs may be safely applied to prevent carcinogenesis and cancer metastasis in human beings. It has been reported that artemisinins possess immunoregulatory properties and modulate components of the immune system (Yao et al., 2016). Abou Rayia et al. (2017) revealed that artemisinin has the potential to be an alternative drug against trichinellosis. Yuan et al. (2019) found that ART ameliorated rosacea-like dermatitis by regulating immune reponse and angiogenesis, indicating that it could represent an effective therapeutic option for patients with rosacea. The mechanism for the antimalarial activity of artemisinin has been examined using artemisinin and its model compounds 1,2,4,5tetraoxane and 1,2,4-trioxolane derivatives (Garah et al., 2011). Chen et al. (2018) suggested that artemisinin had significant anti-tumor activities on $\mathrm{C} 6$ cells both in vitro and in vivo, and artemisinin might be exploited as a promising clinical anti-cancer drug in future. Leng et al. (2019) declared that an extract of an artemisinindeficient Artemisia annua herbal preparation exhibits potent anticancer activity against triple negative human breast cancer. Yao et al. (2018) also concluded that artemisinin derivatives are potential therapeutic agents for the treatment of breast cancer. Konstat-Korzenny et al. (2018) found that both in vitro and in vivo clinical trials have shown promising activity of the artemisinin drug derivatives in treating certain types of cancer. Although, the artemisinin-based combination therapies have become more popular in the fight against malaria, 
resistance to artemisinin has begun to emerge (Shen et al., 2016). Lang et al. (2019) announced that an extract of an artemisinin-deficient Artemisia annua herbal preparation exhibits potent anti-cancer activity against triple negative human breast cancer. Li et al. (2018) indicated that artemisinin exhibited anti-allergic effect by inhibiting ERK activation and increasing Treg cell proportion, which subsequently decreased the expressions of allergic mediators. They have also found that artemisinin combined with neurectomy of pterygoid showed better efficacy than artemisinin alone. Artemisinin also use against liver cancer, brain glioma, leukemia, nasopharyngeal cancer, gallbladder cancer, gastric cancer, cervical cancer, lung cancer, breast cancer and colon cancer through reducing cell proliferation, inducing cell cycle arrest, promoting cell apoptosis, blocking tumor cell invasion, chaning the tumor microenvironment and reducing angiogenesis (Aderibigbe, 2017; Zhang et al., 2018). Munyangi et al. (2018) reported the effective treatment of schistosomiasis by using $A$. annua. Phytochemical constituents of aqueous extract are tannins, anthraquinones, cardic glycosides, saponins, phenolic compounds, flavonoids, alkaloids, terpenoids and steroids, and phytochemical constituents of hexane extract are cardic glycosides, flavonoids, alkaloids, terpenoids and steroids (Abubakar et al., 2018). The major influences of artemisinin and its derivatives are direct manner such are regulating neuroinflammatory processes, anti-oxidative stress, neuroprotection, preventive $A \beta$ accumulation and neurotoxicity, and the main indirect impacts are maintaining $\mathrm{BBB}$ integrity, suppression systemic inflammatory and alleviating intestinal inflammation (Shi et al., 2018). Sarder and Pkharel (2018) reported artemisinin and its derivatives such as artesunate, dihydroartemisinin, anhydrodihydroartemisinin, 10-dihydroartemisinyl acetate, 10dihydroartemisinyl butyrate, 10-(2-butyloxy) dihydroartemisinin, 10-dihydroartemisinyl 2'propylpentanoate, 10-dihydroartemisinyl 2,2-dimethylpropionate, 10-dihydroartemisinyl dimethylcarbamate, 10-dihydroartemisinyl dimethylcarbamate, artemether and arteether. Anti-malarial drugs that have been used in artemisinin combination are chloroquine, piperaquine, amodiaquine, dihydroartemisinin, artesunate, artemether, mefloquine, halofantrine, lumefantrine, pyrimethamine, chlorproguanil, atovaquone, sulfadoxine and dapsone (Nosten and White, 2007).

The plant extract of $A$. annua has a modulatory impact on components of the immune system such as TLR2 and TLR4 (Wojtkowiak-Giera et al., 2019). Dihydroartemisinin showed colon cancer growth by inducing apoptosis and increase the expression of PPAR $\gamma$, which has made it a promising natural compound for the treatment of colon cancer (Lu et al., 2018). Artemisinin and its derivatives for the treatment of various diseases are shown in Table 2.

Table 2. Artemisinin and its derivatives for the treatment of different diseases (Rahman et al., 2019).

\begin{tabular}{|c|c|c|}
\hline Therapeutics & Drugs & Diseases/pathogens \\
\hline Anticancer & Artemisinin & Prostate cancer \\
\hline & Artemisinin & Hepatocellular carcinoma \\
\hline & Artemisinin & Ovary cancer \\
\hline & Artemisinin & Colon cancer \\
\hline & Artemisinin & Cervical cancer \\
\hline & Artesunate & Kaposis sarcoma \\
\hline & Artesunate & Melanoma \\
\hline & Artesunate & Ovarian cancer \\
\hline & Artesunate & Breast cancer \\
\hline & Artesunate & Glioma \\
\hline & Dihydroartemisinin cancer \\
\hline & Dihydroartemisinin & Lung carcinoma \\
\hline & Dihydroartemisinin & Leukemia \\
\hline & Dihydroartemisinin & Osteosarcoma \\
\hline & Dihydroartemisinin & Hepatitis C virus \\
\hline
\end{tabular}


Shahrajabian MH et al. (2020). Not Bot Horti Agrobo 48(4):1719-1741

\begin{tabular}{|c|c|c|}
\hline & Artemisinin & Bovine \\
\hline & Artesunate & Viral diarrhea virus (BVDV) \\
\hline & Artesunate & Herpes virus \\
\hline & Artesunate & Hepatitis B virus \\
\hline & Artesunate & Human cytomegalovirus (HCMV) \\
\hline & Artesunate & HCMV \\
\hline \multirow[t]{5}{*}{ Antischistosomiasis } & Artesunate & Schistosoma haematobium \\
\hline & Artesunate & Schistosoma mansoni \\
\hline & Praziquantel & Schistosoma japonicum \\
\hline & Praziquantel & Schistosoma mansoni \\
\hline & Praziquantel & Schistosoma mekongi \\
\hline \multirow[t]{2}{*}{ Antituberculosis } & Artemisinin & Tuberculosis \\
\hline & Artesunate & Tuberculosis \\
\hline \multirow[t]{11}{*}{ Autoimmune diseases } & Artemisinin & Endometriosis \\
\hline & Artemisinin & Lupus nephritis \\
\hline & Artemisinin & Alzheimer, s Disease \\
\hline & Artesunate & Rheumatoid arthritis \\
\hline & Artesunate & Systemic lupus erythematosus (SLE) \\
\hline & Artesunate & Asthma \\
\hline & Artesunate & Uveitis \\
\hline & Artesunate & Inflammatory bowel disease (IBD) \\
\hline & Artemether & Rheumatoid arthritis \\
\hline & Dihydroartemisinin & SLE \\
\hline & Dihydroartemisinin & $\begin{array}{l}\text { Experimental autoimmune } \\
\text { encephalomyelitis (EAE) }\end{array}$ \\
\hline \multirow[t]{4}{*}{ Antimalarial } & Artemether & Vivax malaria \\
\hline & Arteether & Cerebral malaria \\
\hline & Artesunate & Vivax malaria \\
\hline & Dihydroartemisinin & Vivax malaria \\
\hline
\end{tabular}

The most important pharmacological properties of artemisinin are anti-malarial activity, antiviral, antibacterial, antihelminthis, antiprotozoa, antifungal, anti-inflammatory and anti-tumor properties (Zyad et al., 2017; Qiu et al., 2018). Phenolics enhance artemisinin water solubility and extraction efficiency as phenolics, mainly chlorogenic acids, are highly present in teas from $A$. annua (Carbonara et al., 2012). Higher artemisinin concentrations when multiplied by total leaf dry matter at the higher boron application rates may increase in total artemisinin production per plant (Davies et al., 2011). Wu et al. (2017) reported that antioxidant activity of volatile oils in the flowering and post-flowering stages were stronger than that in preflowering and initial flowering stages. Fu et al. (2020) found that geographic content differences of the components in $A$. annua indicate the potential differences in the health-promoting effects of its clinical application. Its essential oil extracts have a good antioxidant capacity, especially as antiradical scavengers (Gouveia and Castilho, 2013). Artesunate can compromise the repair of DNA double-strand breaks (DSBs) in ovarian cancer cells which shows its ability as a sensitizing agent in chemotherapy (Wang et al., 2015). Artesunate has anti-proliferative properties in colorectal cancer (CRC) and is generally well tolerated (Krishna et al., 2015). The most important pharmaceutical benefits of Artemisia are shown in Table 3. The most important natural components and pharmaceutical benefits of Artemisia annua L is shown in Figure 2. 
Table 3. The most important health benefits of Artemisia

\begin{tabular}{|c|c|c|}
\hline Pharmaceutical benefits & Mechanisms and impacts & References \\
\hline Anti-malarial & $\begin{array}{l}\text { a. Artemisinin is the key anti-malarial } \\
\text { compound of } A \text { annua L. } \\
\text { b. The efficacy of artemisinin against } \\
\text { malaria has promoted its use as a tea } \\
\text { drink in endemic communities. } \\
\text { c. Artemisia appeared to break the } \\
\text { cycle of malaria by eliminating } \\
\text { gametocytes. } \\
\text { d. Artemether is co-administered } \\
\text { with lumefantrine as part of a fixed- } \\
\text { dose combination therapy for malaria } \\
\text { in both adult and pediatric patients. }\end{array}$ & $\begin{array}{l}\text { Mueller et al. (2004) } \\
\text { Atemnken et al. (2009) } \\
\text { Ghafoori et al. (2013) } \\
\text { Abolaji et al. (2014) } \\
\text { Weathers et al. (2014) } \\
\text { Lin et al. (2016) } \\
\text { Xiao et al. (2016) } \\
\text { Baldino et al. (2017) } \\
\text { Munyangi et al. (2019) }\end{array}$ \\
\hline Anti-microbial & $\begin{array}{l}\text { a. The extracts of Artemisia are novel } \\
\text { natural source of antimicrobial agents } \\
\text { for the treatment of microbial } \\
\text { infections. }\end{array}$ & $\begin{array}{l}\text { Viljoen et al. (2006) } \\
\text { Cavar et al. (2012) } \\
\text { Kazemi et al. (2012) } \\
\text { Ashraf et al. (2017) } \\
\text { Li et al. (2017) } \\
\text { Mohamed et al. (2017) } \\
\text { Allam et al. (2019) }\end{array}$ \\
\hline Anti-cancer & $\begin{array}{l}\text { a. The inhibition of immune } \\
\text { mediators of angiogenesis by } \\
\text { sesquiterpene lactones and flavonoids } \\
\text { may be of the mechanisms of } \\
\text { anticancer activity of Artemisia annua } \\
\text { L. } \\
\text { b. The cellular response of artemisinin } \\
\text { and its derivatives such as } \\
\text { dihydroartemisinin, artesunate, } \\
\text { artemether, and arteether towards } \\
\text { cancer cells include oxidative stress } \\
\text { response by reactive oxygen species } \\
\text { and nitric oxide, DNA damage and } \\
\text { repair, various cell death modes, } \\
\text { inhibition of angiogenesis and tumor- } \\
\text { related signal transduction pathways } \\
\text { and signal transducers. } \\
\text { c. Some trioxane dimmers have } \\
\text { selective and very potent anticancer } \\
\text { activity even at low nanomolar } \\
\text { concentrations. } \\
\text { d. An extract of an artemisinin- } \\
\text { deficient Artemisia annua herbal } \\
\text { preparation exhibits potent } \\
\text { anticancer activity against triple } \\
\text { negative human breast cancer. } \\
\text { e. Its dried leaf has high efficacy } \\
\text { against non-small cell lung cancer. }\end{array}$ & $\begin{array}{c}\text { Posner et al. (2006) } \\
\text { Crespo-Ortiz and Wei (2012) } \\
\text { Zhu et al. (2013) } \\
\text { Zhang et al. }(2015) \\
\text { Efferth (2017) } \\
\text { Koul et al. }(2017) \\
\text { Lang et al. }(2019) \\
\text { Omar et al. }(2019) \\
\text { Rassias et al. }(2019)\end{array}$ \\
\hline Anti-fungal & $\begin{array}{l}\text { a. Artemisia oil possess anti-fungal, } \\
\text { insecticidal and larvicidal activity. } \\
\text { b. Coumarins and lignans from } A \text {. } \\
\text { annua have antifungal activities. }\end{array}$ & $\begin{array}{l}\text { Behravan et al. (2006) } \\
\text { Saleh et al. }(2006) \\
\text { Suresh et al. }(2011) \\
\text { Li et al. }(2019)\end{array}$ \\
\hline
\end{tabular}




\begin{tabular}{|c|c|c|}
\hline Anti-bacterial activity & $\begin{array}{l}\text { a. Essential oil Artemisia species } \\
\text { inhibit inhibitory activity against } \\
\text { certain human pathogens. } \\
\text { b. Artemisia species have antibacterial } \\
\text { activity against multi-drug resistance } \\
\text { extended-spectrum } \beta \text {-lactamse } \\
\text { (ESBL) positive Escherichiacoli. } \\
\text { c. Its essential oil may exhibit good } \\
\text { antibacterial activity against } \\
\text { Staphylococcus aureus, } \\
\text { Bacillussubtilis, } \\
\text { Staphylococcusepidermidis, } \\
\text { Salmonella typhimurium and } \\
\text { Streptococcus mutans. } \\
\text { d. Its extract showed cytotoxicity } \\
\text { against oral gingival carcinoma cell. }\end{array}$ & $\begin{array}{c}\text { Lima et al. }(2008) \\
\text { Asili et al. }(2015) \\
\text { Donato et al. }(2015) \\
\text { Goswami et al. }(2016) \\
\text { Lee (2016) } \\
\text { Rafika et al. }(2018)\end{array}$ \\
\hline Anti-oxidant activity & $\begin{array}{l}\text { a. Administration of its extract } \\
\text { ameliorate blood glucose, total } \\
\text { cholesterol, triglycerides, and } \\
\text { malondialdehyde. } \\
\text { b. Essential oil showed antioxidant } \\
\text { activity comparable with thymol. }\end{array}$ & $\begin{array}{c}\text { Ahuja et al. (2011) } \\
\text { Bora and Sharma (2011) } \\
\text { Cavar et al. }(2012) \\
\text { Gouveia and Castilho (2013) } \\
\text { Bourgou et al. }(2016) \\
\text { Mohammadi et al. (2017) } \\
\text { Seiko et al. (2019) } \\
\text { Zhigzhitzhapova et al. (2019) } \\
\text { Messaili et al. (2020) } \\
\text { Ranjbar et al. (2020) }\end{array}$ \\
\hline Anti-complement & $\begin{array}{l}\text { a. The solvent chloroform extracts of } \\
\text { Artemisia plants showed inhibitory } \\
\text { activity against complement system } \\
\text { with } 50 \% \text { inhibitory concentrations. }\end{array}$ & Moon et al. (2012) \\
\hline Hepatoprotective activity & $\begin{array}{l}\text { a. It high hepatoprotective activity is } \\
\text { connected to hydroxycinnamoyl } \\
\text { quinic acids and flavonoids }\end{array}$ & El-Askary et al. (2019) \\
\hline Anti-inflammatory & $\begin{array}{l}\text { a. The flavonoids casticin and } \\
\text { chrysosplenol } \mathrm{D} \text { from } A \text {. annua } \mathrm{L} \text {. } \\
\text { may inhibit inflammation in vitro and } \\
\text { in vivo. } \\
\text { b. } \alpha \text {-bisabolol which is a famous anti- } \\
\text { inflammatory extract found in } \\
\text { essential oil. } \\
\text { c. Artemisinin may protect the aortas } \\
\text { from atherosclerotic lesions by } \\
\text { suppression of inflammatory reaction } \\
\text { via AMPK/NF- } \kappa \mathrm{B} / \mathrm{NLRP} 3 \\
\text { inflammasomes signaling in } \\
\text { macrophages. }\end{array}$ & $\begin{array}{l}\text { Ashok and Upadhyaya (2013) } \\
\text { Li et al. }(2015) \\
\text { Vasylievna et al. }(2015) \\
\text { Jiang et al. }(2020)\end{array}$ \\
\hline Anti-mutagenic & & Taherkhani (2015) \\
\hline Anti-inflammatory & $\begin{array}{l}\text { a. Its essential oil possesses } \\
\text { biologically active constituents which } \\
\text { have significant activity against acute } \\
\text { inflammation and have central and } \\
\text { peripheral antinociceptive effects. } \\
\text { b. Artemisinin may be a potential }\end{array}$ & $\begin{array}{l}\text { Magenta et al. }(2014) \\
\text { Li et al. }(2015) \\
\text { Song et al. }(2017) \\
\text { Wang et al. }(2017) \\
\text { Tadayoni et al. }(2018)\end{array}$ \\
\hline
\end{tabular}




\begin{tabular}{|c|c|c|}
\hline & $\begin{array}{l}\text { useful therapeutic agent for } \\
\text { inflammatory-related diseases. } \\
\text { c. The beneficial clinical effects of } \\
\text { artemisinins for the treatment of } \\
\text { malaria include the apparent ability to } \\
\text { attenuate the inflammatory response. } \\
\text { d. The flavonoids casticin and } \\
\text { chrysosplenol D from } A \text {. annua L. } \\
\text { inhibited inflammation in vitro and } \\
\text { in vivo. } \\
\text { e. The enzymatically treated } \\
\text { Artemisiaannua (EA) } \\
\text { supplementation could alleviate the } \\
\text { intestinal inflammatory response, and } \\
\text { improve the intestinal barrier } \\
\text { function in broilers during the heat } \\
\text { stress period. }\end{array}$ & \\
\hline Anti-tumor & $\begin{array}{l}\text { a. Water-soluble polysaccharide } \\
\text { inhibits HepG2 cell growth via } \\
\text { inducing caspase-dependent } \\
\text { mitochondrial apoptosis and } \\
\text { inhibition of NF- } \kappa \mathrm{B} \text { p } 65 \text {. } \\
\text { b. Its supplementation may alleviate } \\
\text { the intestinal inflammatory response, } \\
\text { and improve the intestinal barrier } \\
\text { function in broilers during the heat } \\
\text { stress period. }\end{array}$ & $\begin{array}{l}\text { Song et al. (2017) } \\
\text { Yan et al. (2019) }\end{array}$ \\
\hline Anti-complement activities & $\begin{array}{l}\text { a. The high contents of galacturonic } \\
\text { acid are important for anti- } \\
\text { complement activities of the } \\
\text { polysaccharides from } A \text {. annua. }\end{array}$ & Huo et al. (2020) \\
\hline Anti-HIV & $\begin{array}{l}\text { a. The } A \text {. annua tea infusion was } \\
\text { found to be highly active with IC } 50 \\
\text { values as low as } 2.0 \mu \mathrm{g} / \mathrm{mL} \text {, and it } \\
\text { provides the in vitro evidence of anti- } \\
\text { HIV activity of } A \text {. annua tea infusion. }\end{array}$ & Lubbe et al. (2012) \\
\hline Anti-plasmodial & $\begin{array}{l}\text { a. Arteannuin } \mathrm{B}(\mathrm{AB}) \text { is one of the } \\
\text { main contributors in } A \text {. annua leading } \\
\text { to enhanced antiplasmodial potency } \\
\text { of QHS via regulation of its } \\
\text { metabolism. }\end{array}$ & Cai et al. (2017) \\
\hline
\end{tabular}



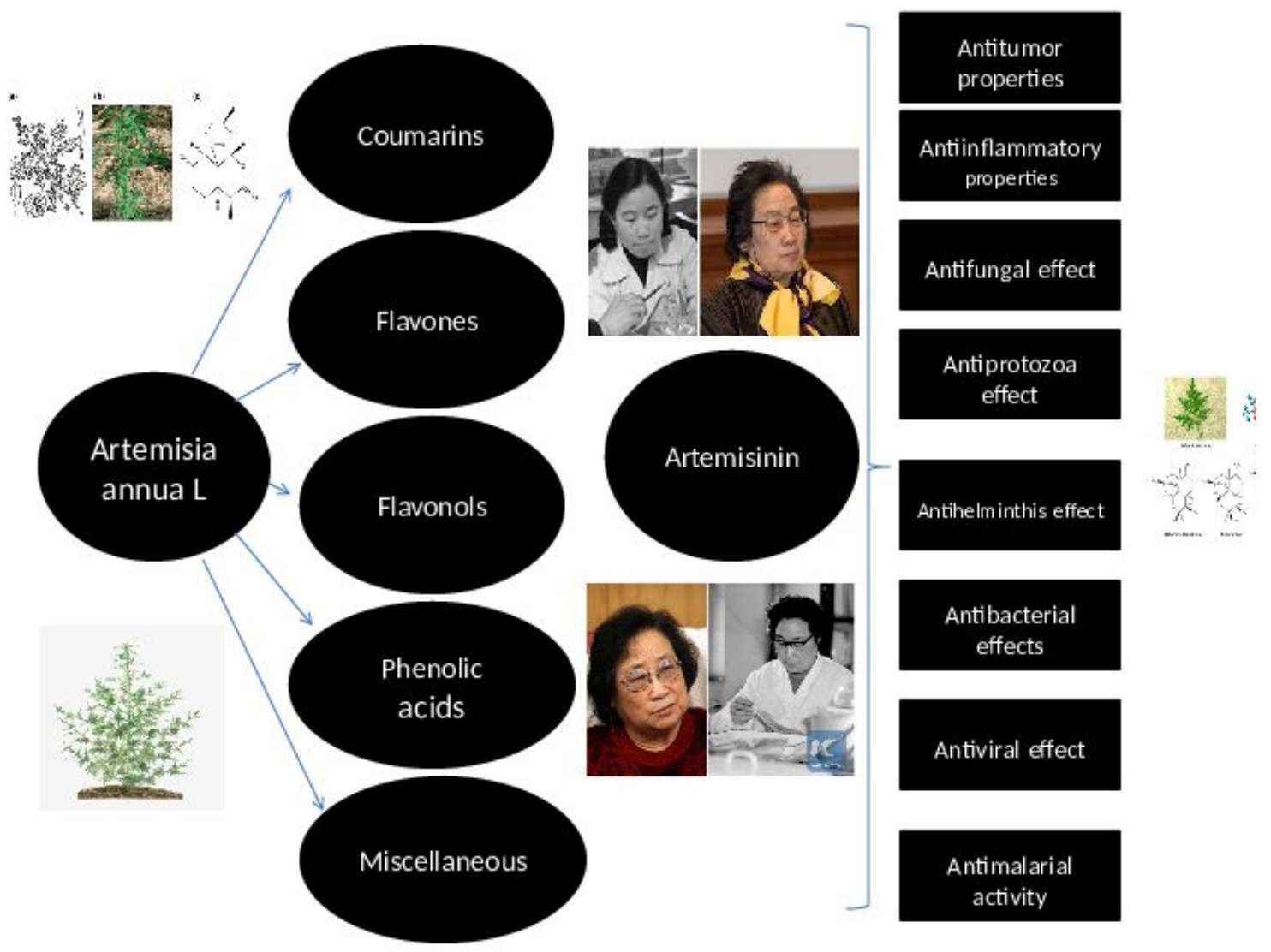

Antibacterial

effects

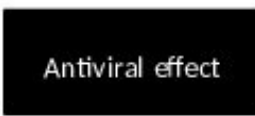

Antimalarial

activity

Figure 2. The most important natural components and pharmaceutical benefits of Artemisia annua L.

\section{Conclusions}

Traditional Chinese medicine is a medical system based on theory, pathology, diagnosis, treatment and herbal pharmacology principles. Artemisia annua L. is a Chinese medicinal herb, which has significant efficacy against malaria with low toxicity. Artemisinin discovered and isolated by Chinese scientists in the early 1970s, as a natural peroxide drug for the treatment of malarial. Artemisinin combination therapies are used worldwide as the appropriate treatment against Plasmodium falciparum malaria. This important drug has been developed from the Chinese traditional herbal medicine and is known as Qinghaosu. Artemisinin demonstrates prominent biological activities and attracts great attention nowadays. Artemisinin and its derivatives, namely artemiside, artesunate, artemisone, arteether, artemether, and dihydroartemisinin have significant anti-malaria, anti-viral, anti-fungal, anti-cancer and anti-inflammatory properties. The artemisinin content is highly dependent on plant ecotypes, ecological interactions, seasonal and geographical variations. The discovery of artemisinin has been presented as the important example of the face of adversity, social commitment to the good of humanity, genuine esteem for past and traditional wisdom and of course a heartfelt belief in the value of science. More researchers of relationship of artemisinin and its derivatives are necessary to develop and optimize new therapeutics with significant impacts. On the basis of traditional Chinese medicine, the metabolic properties of artemisinin and its derivatives bring more hope to treat malaria, obesity and some other metabolic diseases. 


\section{Authors' Contributions}

All authors read and approved the final manuscript.

\section{Acknowledgements}

This research received no specific grant from any funding agency in the public, commercial, or not-forprofit sectors.

\section{Conflict of Interests}

The authors declare that there are no conflicts of interest related to this article.

\section{References}

Abba ML, Patil N, Leupold JH, Saeed MEM, Efferth T, Allgayer H (2018). Prevention of carcinogenesis and metastasis by Artemisinin-type drugs. Cancer Letters 429:11-18. http://doi.org/10.1016/j.canlet.2018.05.008

Abolaji AO, Eteng MU, Ebong PE, Dar A, Farombi EO, Choudhary MI (2014). Artemisia annua as a possible contraceptive agent: a clue from mammalian rat model. Natural Product Research 28(24):2342-2346. http://doi.org/10.1080/14786419.2014.936016

Abou Rayia DM, Saad AE, Ashour DS, Oreiby RM (2017). Implication of artemisinin nematocidal activity on experimental trichinellosis: in vitro and in vivo studies. Parasitology International 66(2):56-63. http://doi.org/10.1016/j.parint.2016.11.012

Abubakar US, Yusuf KM, Abdullahi MS, Abdu GT, Abdulrazak A, Muhammad S, ... Aliyu I (2018). Cultivation, phytochemical and in vitro anti-plasmodium activity of Artemisia annua L. (Asteraceae). Journal of Medicinal Plans Studies 6(4):151-155.

Aderibigbe BA (2017). Design of drug delivery systems containing artemisinin and its derivatives. Molecules 22:323. https://doi.org/10.3390/molecules22020323

Ahuja J, Suresh J, Paramakrishnan N, Mruthunjaya K, Naganandhini MN (2011). An ethnomedical, phytochemical and pharmacological profile of Artemisia parviflora Roxb. Journal of Essential Oil-Bearing Plants 14(6):647-657. https://doi.org/10.1080/0972060X.2011.10643985

Allam H, Benamar H, Mansour RB, Ksouri R, Bennaceur M (2019). Phenolic composition, antioxidant, and antibacterial activities of Artemisia judaica subsp. sahariensis. Journal of Herbs, Spices and Medicinal Plants 25(4):347-362. https://doi.org/10.1080/10496475.2019.1631928

Angus BJ, Thaiaporn I, Chanthapadith K, Suputtamongkol Y, White NJ (2002). Oral artesunate dose-response relationship in acute Falciparum malaria. Antimicrobial Agents and Chemotherapy 46:778-782. https://doi.org/10.1128/AAC.46.3.778-782.2002

Aquino I, Perazzo FF, Maistro EL (2011). Genotoxicity assessment of the antimalarial compound artesunate in somatic cells of mice. Food and Chemical Toxicology 49:1335-1339. https://doi.org/10.1016/j.fct.2011.03.016

Asano M, Iwahashi H (2017). Determination of the structures of radicals formed in the reaction of antimalarial drug artemisinin with ferrous ions. European Journal of Medicinal Chemistry 127:740-747. https://doi.org/10.1016/j.ejmech.2016.10.053

Ashok PK, Upadhyaya K (2013). Evaluation of analgesic and anti-inflammatory activities of aerial parts of Artemisia vulgaris L. in experimental animal models. Journal of Biologically Active Products from Nature 3(1):101-105. https://doi.org/10.1080/22311866.2013.782761

Ashraf A, Sarfraz RA, Mahmood A (2017). Phenolic compounds characterization of Artemisia rutifolia spreng from Pakistani flora and their relationships with antioxidant and antimicrobial attributes. International Journal of Food Properties 20(11):2538-2549. https://doi.org/10.1080/10942912.2016.1243556 
Asili J, Emami SA, Eynolghozat R, Noghab ZS, Bazzaz BSF, Sahebkar A (2015). Chemical composition and in vitro efficacy of essential oil of seven Artemisia species against ESBL producing multidrug-resistant Escherichia coli. Journal of Essential Oil-Bearing Plants 18(1):124-145. https://doi.org/10.1080/0972060X.2014.895181

Atemnkeng MA, Chimanuka B, Dejaegher B, Heyden YV, Plaizier-Vercammen J (2009). Evaluation of Artemisia annua infusion efficacy for the treatment of malaria in chabaudi Plasmodium chabaudi infected mice. Experimental Parasitology 122(4):344-348. https://doi.org/10.1016/j.exppara.2009.04.004

Baldino L, Reverchon E, Porta GD (2017). An optimized process for SC-CO 2 extraction of antimalarial compounds from Artemisia annua L. The Journal of Supercritical Fluids 128:89-93. https://doi.org/10.1016/j.supflu.2017.05.018

Beekman AC, Wierenga PK, Woerdenbag HJ, Van Uden W, Pras N, KoningsAW, ... Wikstrom HV (1998). Artemisininderived sesquiterpene lactones as potential antitumor compounds: cytotoxic action against bone marrow and tumour cells. Planta Medica 64:615-619. https://doi.org/10.1055/s-2006-957533

Behravan J, Ramezani M, Hassanzadeh MK, Eliaspour N, Sabeti Z (2006). Cytotoxic and antimycotic activities of essential oil from Artemisia turanica Krasch from Iran. Journal of Essential Oil-Bearing Plants 9(2):196-203. https://doi.org/10.1080/0972060X.2006.10643492

Bhakuni RS, Jain DC, Sharma RP, Kumar S (2001). Secondary metabolites of Artemisia annua and their biological activity. Current Science 80:35-48.

Bigoniya P, Sahu T, Tiwari V (2015). Hematological and biochemical effects of sub-chronic artesunate exposure in rats. Toxicology Reports 2:280-288. https://doi.org/10.1016/j.toxrep.2015.01.007

BiliaAR, Melillo de Malgalhaes P, Bergonzi MC, Vincieri FF (2006). Simultaneous analysis of artemisinin and flavonoids of several extracts of Artemisia annua L. obtained from a commercial sample and a selected cultivar. Phytomedicine 13:487-493. https://doi.org/10.1016/j.phymed.2006.01.008

Bora KS, Sharma A (2011). Evaluation of antioxidant and free-radical scavenging potential of Artemisia absinthium. Pharmaceutical Biology 49(12):1216-1223. https://doi.org/10.3109/13880209.2011.578142

Bourgou S, Tammar S, Salem N, Mkadmini K, Msaada K (2016). Phenolic composition, essential oil, and antioxidant activity in the aerial part of Artemisia Herba-Alba from several provenances: A comparative study. International Journal of Food Properties 19(3):549-563. https://doi.org/10.1080/109422912.2015.1040495

Brisibe EA, Udensi O, Chukwurah PN, de Magalhaes PM, Figueira GM, Ferreira JFS (2012). Adaptation and agronomic performance of Artemisia annua L. under lowland humid tropical conditions. Industrial Crops and Products 39:190-197. https://doi.org/10.1016/j.indcrop.2012.02.018

Cai T-Y, Zhang Y-R, Ji J-B, Xing J (2017). Investigation of the component in Artemisia annua L. leading to enhanced antiplasmodial potency of artemisinin via regulation of its metabolism. Journal of Ethnopharmacology 207:86-91. https://doi.org/10.1016/j.jep.2017.06.025

Carbonara T, Pascale R, Argentieri MP, Papadia P, Fanizzi FP, Villanova L, Avato P (2012). Phytochemical analysis of a herbal tea from Artemisia annua L. Journal of Pharmaceutical and Biomedical Analysis 65:79-86. http://doi.org/10.1016/j.jpba.2012.01.015

Cavar S, Maksimovic M, Vidic D, Paric A (2012). Chemical composition and antioxidant and antimicrobial activity of essential oil of Artemisia annua L. from Bosnia. Industrial Crops and Products 37(1):479-485. https://doi.org/10.1016/j.indcrop.2011.07.024

Charles DJ, Cebert E, Simon JE (1991). Characterization of the essential oil of Artemisiaannua L. Journal of Essential Oil Research 3(1):33-39. https://doi.org/10.1080/10412905.1991.9697903

Chen J, Zhang L, Hao M (2018). Effect of artemisinin on proliferation and apoptosis-related protein expression in vivo and in vitro. Saudi Journal of Biological Sciences 25:1488-1493. https://doi.org/10.1016/j.sjbs.2018.04.003

Christian J, Shah P, Patel M, Patel K, Ganghi T (2017). Optimizing derivatization conditions using an experimental design and simultaneous estimate of artemether and lumefantrine by ratio first order derivative spectrophotometric method. Journal of Taibah university for Science 11(5):729-740. https://doi.org/10.1016/j.jtusci.2016.08.003

Correa-Ferreira ML, Viudes EB, De MagalhaesPM, Filho APDS, Sassaki GL, Pacheco AC, Petkowicz CLDO (2019). Changes in the composition and structure of cell wall polysaccharides from Artemisia annua in response to salt stress. Carbohydrate Research 483:107753. https://doi.org/10.1016/j.carres.2019.107753

Crespo MP, Wei MQ (2012). Antitumor activity of artemisinin and its derivatives: from a well-known antimalarial agent to a potential anticancer drug. Journal of Biomedicine and Biotechnology 2(4):247597. https://doi.org/10.1155/2012/247597 
Daddy NB, Kalisya LM, Bagire PG, Watt RL, Towler MJ, Weathers PJ (2017). Artemisia annua dried leaf tablets treated malaria resistant to ACT and i.v. artesunate: case reports. Phytomedicine 32(15):37-40. https://doi.org/10.1016/j.phymed.2017.04.006

Davies MJ, Atkinson CJ, Burns C, Arroo R, Woolley J (2011). Increases in leaf artemisinin concentration in Artemisia annua in response to the application of phosphorus and boron. Industrial Crops and Products 34(3):1465-1473. https://doi.org/10.1016/j.indcrop.2011.05.002

DelabaysN, Simonnet X, Gaudin M (2001). The genetics of artemisnin content in Artemisia annua L. and the breeding of high yielding cultivars. Current Medicinal Chemistry 8:1795-1801. https://doi.org/10.2174/0929867013371635

De Oliveira TC, Silva DA, Rostkowska C, Bela SR, Ferro EA, Magalhaes PM, Mineo JR (2009). Toxoplasma gondii: effects of Artemisia annua L. on susceptibility to infection in experimental models in vitro and in vivo. Experimental Parasitology 122:233-241. https://doi.org/10.1016/j.exppara.2009.04.010

Donato R, Santomauro F, Bilia AR, Flamini G, Sacco C (2015). Antibacterial activity of Tuscan Artemisia annua essential oil and its major components against some foodborne pathogens. LWT-Food Science and Technology 64:12511254. https://doi.org/10.1016/j.lwt.2015.07.014

Efferth T (2017). From ancient herb to modern drug: Artemisia annua and artemisinin for cancer therapy. Seminars in Cancer Biology 46:65-83. https://doi.org/10.1016/j.semcancer:2017.02.009

El-Askary H, Handoussa H, Badira F, El-Khatib AH, Alsayari A, Linscheid MW, Motaal AA (2019). Characterization of hepatoprotective metabolites from Artemisia annua and Cleome droserifolia using HPLC/PDA/ESI/MS-MS. Revista Brasileira de Farmacognosia 29:213-220. https://doi.org/10.1016/j.bjp.2018.10.001

El-Naggar EB, Azazi M, Svajdlenka E, Zemlicka M (2013). Artemisinin from minro to major ingredient in Artemisia annua cultivated in Egypt. Journal of Applied Pharmaceutical Science 3(08):116-123.

Fathy FM (2011). Anthelmintic effect of artesunate in experimental heterophyid infection. Journal of the Egyptian Society of Parasitology 41:469-483.

Ferreira JFS, Luthria DL, Sasaki T, Heyerick A (2010). Flavonoids from Artemisia annua L. as antioxidants and their potential synergism with artemisinin against malaria and cancer. Molecules 15(5):3135-3170. https://doi.org/10.3390/molecules15053135

Fu J-E, Feng L, Wei S-G, Ma X-J, Huang E-S, Feng S-X, Dong Q-S, Yan Z-G (2016). Distinctive morphological characteristics contribute to the identification of Artemisia annua L. germplasms with high yield and high artemisinin content. Journal of Applied Research on Medicinal and Aromatic Plants 3:43-47. https://doi.org/10.1016/j.jarmap.2015.12.004

Fu C, Yu P, Wang M, Qiu F (2020). Phytochemical analysis and geographic assessment of flavonoids, coumarins and sesquiterpenes in Artemisia annua L. based on HPLC-DAD quantification and LC-ESI-QTOF-MS/MS confirmation. Food Chemistry 312:126070. https://doi.org/10.1016/j.foodchem.2019.126070

Garah FBE, Wong MH, Amewu RK, Muangnoicharoen S, Maggs JL, Stigliani JL... O'Neill PM (2011). Comparison of the reactivity of antimalarial 1,2,4,5-Tetraoxanes with 1,2,4-Trioxolanes in the presence of ferrous iron salts, heme, and ferrous iron salt/phosphatidylcholine. Journal of Medicinal Chemistry 54:6442-6455. https://doi.org/10.1021/jm200768h

Ghafoori H, Sariri R, Naghavi MR, Aryakia E, Dolatyari A, Shahzadeh FSA, ... Farahmand Z (2013). Analysis of artemisinin isolated from Artemisia annua L. by TLC and HPLC. Journal of Liquid Chromatography and Related Technologies 36(9):1198-1206.

Goel D, Mallavarupu GR, Kumar S, Singh V, Ali M (2008). Volatile metabolite compositions of the essential oil from aerial parts of ornamental and artemisinin rich cultivars of Artemisia annua. Journal of Essential Oil Research 20(2):147-152. https://doi.org/10.1080/10412905.2008.9699976

Goswami P, Chauhan A, Verma RS, Padalia R, Verma SK, Darokar MP, Chanotuya CS (2016). Composition and antibacterial activity of the essential oil of Artemisia nilagirica var. septentrionalis from India. Journal of Essential Oil Research 28(1):71-76. https://doi.org/10.1080/10412905.2015.1083489

Gouveia SC, Castilho P (2013). Artemisia annua L.: Essential oil and acetone extract composition and antioxidant capacity. Industrial Crops and Products 45:170-181. https://doi.org/10.1016/j.indcrop.2012.12.022

Gugliandolo E, D'Amico R, Cordaro M, Fusco R, Siracusa R, Crupi R (2018). Neuroprotective effect of artesunate in experimental model of traumatic brain injury. Frontiers in Neurology 9:590. https://doi.org/10.3389/fneur.2018.00590 
Habibi Z, Ghanian S, Ghasemi S, Yousefi M (2013). Chemical composition and antibacterial activity of the volatile oil from seeds of Artemisia annua L. from Iran. Natural Product Research 27(2):198-200. https://doi.org/10.1080/14786419.2012.662652

Hethelyi EB, Cseko IB, Grosz M, Mark G, Palinkas JJ (1995). Chemical composition of the Artemisia annua essential oils from Hungary. Journal of Essential Oil Research 7(1):45-48.

Ho WE, Peh HY, Chan TK, Wong WS (2014). Artemisinins: pharmacological actions beyond anti-malaria. Pharmacology and Therapeutics 142(1):126-139. https://doi.org/10.1080/10412905.1995.9698460

Hou L, Huang H (2016). Immune suppressive properties of artemisinin family drugs. Pharmacology and Therapeutics 166:123-127. https://doi.org/10.1016/j.pharmthera.2016.07.002

Huang L, Xie C, Duan B, Chen S (2010). Mapping the potential distribution of high artemisinin-yielding Artemisia annua L. (Qinghao) in China with a geographic information system. Chinese Medicine 5:18. https://doi.org/10.1186/1749-8546-5-18

Huo J, Lu Y, Xia L, Chen D (2020). Structural characterization and anticomplement activities of three acidic homogenous polysaccharides from Artemisiaannua. Journal of Ethnopharmacology 247:112281. https://doi.org/10.1016/j.jep.2019.112281

IkramNKBK, Simonsen HT (2017). A review of biotechnological artemisinin production in plants. Frontiers in Plant Science. Volume 8, Article 1966. https://doi.org/10.3389/fpls.2017.01966

Ivanescu B, Vlase L, Corciova A, Lazar MI (2011). Artemisinin evaluating in Romanian Artemisia annua wild plants using a new HPLC/MC method. Natural Prodcut Research 25(7):716-722. https://doi.org/10.1080/14786410903169847

Jain N, Srivastava SK, Aggarwal KK, Kumar S, Syamasundar KV (2002). Essential oil composition of Artemisia annua L. 'Asha' from the plains of Northern India. Journal of Essential Oil Research 14(4):305-307. https://doi.org/10.1080/10412905.2002.9699863

Jiang Y, Du H, Liu X, Fu X, Li X, Cao Q (2020). Artemisinin alleviates atherosclerotic lesion by reducing macrophage inflammation via regulation of AMPK/NF- $\mathrm{kB} / \mathrm{NLRP3}$ inflammasomes pathway. Journal of Drug Targeting 28(1):70-79. https://doi.org/10.1080/1061186X.2019.1616296

Kannan D, Yadav N, Ahmad S, Namdev P, Bhattacharjee S, Lochab B, Singh S (2019). Pre-clinical study of iron oxide nanoparticles fortified artesunate for efficient targeting of malarial parasite. EBioMedicine 45:261-277. https://doi.org/10.1016/j.ebiom.2019.06.026

Kazemi M, Dakhili M, Davari M (2012). Constituents and antimicrobial activity of essential oil of Artemisia lehmanniana Bunge from Iran. Journal of Essential Oil-Bearing Plants 15(3):392-398. https://doi.org/10.1080/0972060X.2012.10644066

Kazemi M (2015). Essential oil of the aerial parts of Artemisia annua (Asteraceae) from Iran. Journal of Essential OilBearing Plants 18(4):1003-1005. https://doi.org/10.1080/0972060X.2014.931256

Keiser J, Ingram K, Vargas M, Chollet J, Wang X, Dong Y, Vennerstrom JL (2012). In vivo activity of aryl ozonides against Schistosoma species, Antimicrob. Agents Chemother 56(2):1090-1092. https://doi.org/10.1128/AAC.0537111

Komori A, Suzuki A, Seki H, Nishizawa T, Meyer JJM, Shimizu H, ... Muranaka T (2013). Comparative functional analysis of CYP71AV1 natural variants reveals an important residue for the successive oxidation of amorpha-4, 11-diene. FEBS Letters 587:278-284. https://doi.org/10.1016/j.febslet.2012.11.031

Kong Z, Liu R, Cheng Y(2019). Artesunate alleviates liver fibrosis by regulating ferroptosis signaling pathway. Biomedicine and Pharmacotherapy 109:2043-2053. https://doi.org/10.1016/j.biopha.2018.11.030

Konstat-Korzenny E, Ascencio-Aragon JA, Niezen-Lugo S, Vazquez-Lpoez R (2018). Artemisinin and its synthetic derivatives as a possible therapy for cancer. Medical Sciences 6:19. https://doi.org/10.3390/medsci6010019

Koul B, Taak P, Kumar A, Khatri T, Sanyal I (2017). The Artemisia genus: a review of traditional uses, phytochemical constituents, pharmacological properties and germplasm conservation. Journal of Glycomics \& Lipidomics 7:1. https://doi.org/10.4172/2153-0637.1000142

Krishna S, Ganapathi S, Ster IC, Saeed MEM, Cowan M, Finlayson C, ... Kumar D (2015). A randomized, double blind, placebo-controlled pilot study of oral artesunate therapy for colorectal cancer. EBioMedicine 2:82-90. https://doi.org/10.1016/j.ebiom.2014.11.010

Kuster T, Kriegel B, Stadelmann X, Wang Y, Dong JL, VennerstromJ, ... Hemphill A (2014). Hempill, Amino ozonides exhibit in vitro activity against Echinococcus multilocularis metacestodes. International Journal of Antimicrobial Agents 43(1):40-46. https://doi.org/10.1016/j.ijantimicag.2013.09.012 
Lai H, Sasaki T, Singh NP (2005). Targeted treatment of cancer with artemisinin and artemisinin-tagged iron-carrying compounds. Expert Opinion on Therapeutic Targets 9(5):995-1007. https://doi.org/10.1517/14728222.9.5.995

Lai HC, Singh NP, Sasaki T (2013). Development of artemisinin compounds for cancer treatment. Investigation New Drugs 31:230-246. https://doi.org/10.1007/s10637-012-9873-Z

Lam NS, Long X, Su X-Z, Lu F (2018). Artemisinin and its derivatives in treating helminthic infections beyond schistosomiasis. Pharmacological Research133:77-100. https://doi.org/10.1016/j.phrs.2018.04.025

Lang SJ, Schmiech M, Hafner S, Paetz C, Steinborn C, Huber R, ... Simmet T (2019). Antitumor activity of an Artemisia annua herbal preparation and identification of active ingredients. Phytomedicine 62:152962. https://doi.org/10.1016/j.phymed.2019.152962

Lee J-H (2016). Antibacterial activity against oral pathogens and anti-oral cancer activity of Artemisia species in vitro. Journal of Herbs, Spices and Medicinal Plants 22(2):130-138. https://doi.org/10.1080/10496475.2015.1091424

Li Y-J, Guo Y, Yang Q, Weng X-G, Yang L, Wang Y-J, ... Zidek Z (2015). Flavonoids casticin and chrysosplenol D from Artemisia annua L. inhibit inflammation in vitro and in vivo. Toxicology and Applied Phamacology 286(3):151158. https://doi.org/10.1016/j.taap.2015.04.005

Li Y, Xia L, Vazquez JFT, Song S (2017). Optimization of supercritical $\mathrm{CO}_{2}$ extraction of essential oil from Artemisia annua L. by means of response surface methodology. Journal of Essential Oil-Bearing Plants 20(2):314-327. https://doi.org/10.1080/0972060X.2017.1298475

Li J, Wang B, Luo Y, Bian Y, Wang R (2018). Effect of artemisinin and neurectomy of pterygoid canal in ovalbumininduced allergic rhinitis mouse model. Allergy, Asthma \& Clinical Immunology 14:22.

Li K-M, Dong X, Ma Y-N, Wu Z-H, Yan Y-M, Cheng Y-X (2019). Antifungal coumarins and lignans from Artemisia annua. Fitoterapia 134:323-328.

Li X, He J, Lian Y, Li F, Suo, Jin G (2020). The complete chloroplast genome sequence of Artemisia ordosica. Mitochondrial DNA Part B 5(3):2180-2181.

Libbey LM, Sturtz G (1989). Unusual essential oils grown in Oregon II. Artemisia annua L. Journal of Essential Oil Research 1(5):201-202.

Lim CE, Kim G-B, RyuS-A, Yu H-J, Mun J-H (2018). The complete chloroplast genome of Artemisia hallaisanensis Nakai (Asteraceae) and endemic medicinal herb in Korea. Mitochondrial DNA Part B 3(1):359-360. https://doi.org/10.1080/23802359.2018.1450680

Lima B, de Lampasona MP, Schuff C, Tapia A, Bomben R, Duschatzky C, Feresin GE (2008). Chemical composition and antibacterial activity of Artemisia mendozana D. C. essential oil. Journal of Essential Oil-Bearing Plants 11(5):496-502. https://doi.org/10.1080/0972060X.2008.10643658

Lin W, Heimbach T, Jain JP, Awasthi R, Hamed K, Sunkara G, He H (2016). A physiologically based pharmacokinetic model to describe artemether pharmacokinetics in adult and pediatric patients. Journal of Pharmaceutical Sciences 105:3205-3213. https://doi.org/10.1016/j.xphs.2016.06.026

Liu H, Tian X, Zhang Y, Wang C, Jiang H (2013). The discovery of Artemisia annua L. in the Shengindian cemetery, Xinjiang, China and its implications for early uses of traditional Chinese herbal medicine qinghao. Journal of Ethnopharmacology 146(1):278-286. https://doi.org/10.1016/j.jep.2012.12.044

Liu H, Guo S-S, Lu L, Li D, Liang J, Huang Z-H, ... Du S (2019). Essential oil from Artemisia annua aerial parts: composition and repellent activity against two storage pests. Natural Product Research. https://doi.org/10.1080/14786419.2019.1599887

Lohani H, Gwari G, Bhandari U, Haider SZ, Andola H, Chauhan N (2016). Variability in the essential oils from aerial parts of Artemisia vulgaris L. grown in Uttarakhand (India). Journal of Essential Oil-Bearing Plants 19(1):103107. https://doi.org/10.1080/0972060X.2015.1127784

Lu Z-H, Peng J-H, Zhang R-X, Wang F, Sun H-P, Fang Y-J, ... Pan Z-Z (2018). Dihydroartemisinin inhibits colon cancer cell viability by inducing apoptosis through up-regulation of PPAR $\gamma$ expression. Saudi Journal of Biological Sciences 25:327-376. https://doi.org/10.1016/j.sjbs.2017.02.002

Lu F, He X-L, Richard C, Cao J (2019). A brief history of artemisinin: modes of action and mechanisms of resistance. Chinese Journal of Natural Medicines 17(5):0331-0336. https://doi.org/10.1016/S1875-5364(19)30038-X

Lu K, Mao W, Du Z, He Y, Fan C, Zhang K, ... Duan Y (2020). The complete chloroplast genome sequence of Artemisia ordosica. Mitochondrial DNA Part B 5(2):1663-1664. https://doi.org/10.1080/23802359.2020.1748530

Lubbe A, Seibert I, KlimkaitT, Van der Kooy F (2012). Ethnopharmacology in overdrive: The remarkable anti-HIV activity of Artemisia annua. Journal of Ethnopharmacology 141(3):854-859. https://doi.org/10.1016/j.jep.2012.03.024 
Lv Z, Zhang L, Tang K (2017). New insights into artemisinin regulation. Plant Signaling and Behavior 12(10):e1366398. https://doi.org/10.1080/15592324.2017.1366398

Lv Z, Zhang L, Chen L, Zhang F, Tang K (2018). The Artemisia annua flowering locust homolog 2, AaFT2, is a key regulator of flowering time. Plant Physiology and Biochemistry 126:197-205. https://doi.org/10.1016/j.plaphy.2018.02.033

Lv Z, Wang Y, Liu Y, Peng B, Zhang L, Tang K, Chen W (2019). The SPB-box transcription factor AaSPL2 positively regulates artemisinin biosynthesis in Artemisia annua L. Frontiers in Plant Science. Volume 10, Article 409. https://doi.org/10.3389/fpls.2019.00409

Ma C, Wang H, Lu X, Li H, Liu B, Xu G (2007). Analysis of Artemisia annua L. volatile oil by comprehensive twodimensional gas chromatography time-of-flight mass spectrometry. Journal of Chromatography A 1150(1-2):5053. https://doi.org/10.1016/j.chroma.2006.08.080

Madbouly NA, Shalash IR, El Deeb SO, El Amir AM (2015). Effect of artemether on cytokine profile and egg induced pathology in murine Schistosomiasis mansoni. Journal of Advanced Research 6:851-857. https://doi.org/10.1016/j.jare.2014.07.003

Magenta D, Sangiovanni E, Basilico N, Haynes RK, Parapini S, Colombo E, ... Dell-Agli M(2014). Inhibition of metalloproteinase-9 secretion and gene expression by artemisinin derivatives. Acta Tropica 140:77-83. https://doi.org/10.1016/j.actatropica.2014.08.008

Magoulas GE, Tsigkou T, Skondra L, Lamprou M, TsoukalaP, Kokkinogouli V, Pantazaka E, Papioannou D, Athanassopoulos CM, Papadimitriou E (2017). Synthesis of novel artemisinin dimmers with plyamine linkers and evaluation of their potential as anticancer agents. Bioorganic and Medicinal Chemistry 25:2756-3767. https://doi.org/10.1016/j.bmc.2017.05.018

Malik AA, Ahmad J, Mir SR, Ali M, Abdin MZ (2009). Influence of chemical and biological treatments on volatile oil composition of Artemisia annua Linn. Industrial Crops and Products 30(3):380-383. https://doi.org/10.1016/j.indcrop.2009.07.006

Meshnick SR, TaylorTE, Kamchonwongpaisan S (1996). Artemisinin and the anti-malarial endoperoxides from herbal remedy to targeted chemotherapy. Microbiological Reviews 60(2):301-315. https://doi.org/10.1128/MMBR.60.2.301-315.1996

Messaili S, Colas C, Fougere L, Destandau E (2020). Combination of molecular network and centrifugal partition chromatography fraction for targeting and identifying Artemisia annua L. antioxidant compounds. Journal of Chromatography A 1615:460785. https://doi.org/10.1016/j.chroma.2019.460785

MirzaeeH, Sharafi A, Sohi HH (2016). In vitro regeneration and transient expression of recombinant sesquiterpene cyclase (SQC) in Artemisia annua L. South African Journal of Botany 104:225-231. https://doi.org/10.1016/j.sajb.2015.10.005

Mishina YV, Krishna S, Hynes RK, Meade JC (2007). Artemisinins inhibit Trypanosoma cruzi and Trypanosoma bruceirhodesiense in vitro growth. Antimicrobial Agents and Chemotherapy 51:1852-1854. https://doi.org/10.1128/AAC.01544-06

Mohamed TA, Hegazy M-EF, El Aty AAA, Ghabbour HA, Alsaid MS, Shahat AA, Pare PW (2017). Antimicrobial sesquiterpene lactones from Artemisiasieberi. Journal of Asian Natural Products Research 19(11):1093-1101. https://doi.org/10.1080/10286020.2017.1302939

Mohammadi A, Arianfar A, Noori M (2017). Chemical composition, antioxidant and antibacterial activity of Artemisia diffusa essential oil. Journal of Essential Oil-Bearing Plants 20(5):1235-1243. https://doi.org/10.1080/0972060X.2017.1345329

Moon H-I, Jung S, Lee Y-C, Lee J-H (2012). Anticomplement activity of various solvent extracts from Korea local Artemisia spp. Immunopharmacology and Immunotoxicology 34(1):95-97. https://doi.org/10.3109/08923973.2011.581286

Mueller MS, Runyambo N, Wagner I, Borrmann S, Dietz K, Heide L (2004). Randomized controlled trial of a traditional preparation of Artemisia annua L. (Annual Wormwood) in the treatment of malaria. Transactions of the Royal Society of tropical Medicine and Hygiene 98(5):318-321. https://doi.org/10.1016/j.trstmh.2003.09.001

Munyangi J, Cornet-Vernet L, Idumbo M, Lu C, Lutgen P, Perronne C, ... Weathers P (2018). Effect of Artemisia annua and Artemisia afra tea infusions on schistosomiasis in a large clinical trial. Phytomedicine 51:233-240. https://doi.org/10.1016/j.phymed.2018.10.014

Munyangi J, Cornet-Vernet L, Idumbo M, Lu C, Lutgen P, Perronne C, ... Weathers P (2019). Artemisia annua and Artemisia afra tea infusions vs. artesunate-amodiaquine (ASAQ) in treating Plasmodium falciparum malaria in a 
Shahrajabian MH et al. (2020). Not Bot Horti Agrobo 48(4):1719-1741

large scale, double blind, randomized clinical trial. Phytomedicine 57:49-56. https://doi.org/10.1016/j.phymed.2018.12.002

$\mathrm{NaB}$ J, Efferth T (2019). Development of artemisinin resistance in malaria therapy. Pharmacological Research 146:104275. https://doi.org/10.1016/j.phrs.2019.104275

Negi AS, Cortesi A, Kikic I, Bertucco A, Calabrese M, Solinas D (2018). Desorption of artemisinin extracts of CIMArogya by supercritical carbon dioxide. The Journal of Supercritical Fluids 133:42-48. https://doi.org/10.1016/j.supflu.2017.09.024

Njuguna NM, Ongarora DS, Chibale K (2012). Artemisinin derivatives: a patent review (2006 - present). Expert Opinion on Therapeutic Patents 22:1179-1203. https://doi.org/10.1517/13543776.2012.724063

Nosten F, White NJ (2007). Artemisinin-based combination treatment of falciparum malaria. The American Journal of Tropical Medicine and Hygiene 77(6):181-192. https://doi.org/10.4269/ajtmh.2007.77.181

Noubiap JJ (2014). Shifting from quinine to artesunate as first-line treatment of severe malaria in children and adults: saving more lives. Journal of Infection and Public Health 7:407-412. https://doi.org/10.1016/j.jiph.2014.04.007

O'Neill P (2005). The therapeutic potential of semi-synthetic artemisinin and synthetic endoperoxide antimalarial agents. Expert Opinion on Investigational Drugs 14(9):1117-1128. https://doi.org/10.1517/13543784.14.9.1117

Omar AM, Dibwe DF, Tawila AM, Sun S, Kim MJ, Awale S (2019). Chemical constituents from Artemisia vulgaris and their antiausterity activities against the PANC-1 human pancreatic cancer cell line. Natural Product Research. https://doi.org/10.1080/14786419.2019.1700246

Pan WS, Zheng LP, Tian H, LiWY, Wang JW (2014). Transcriptome responses involved in artemisinin production in Artemisia annua L. under UV-B radiation. Journal of Photochemistry and Photobiology B: Biology 140:292-300. https://doi.org/10.1016/j.jphotobiol.2014.08.013

Phyo AP, Win KK, Thu AM, Swe LL, Htike H, Beau C, ... Nosten F (2018). Poor response to artesunate treatment in two patients with severe malaria on the Thai-Myanmer border. Malaria Journal 17:30. https://doi.org/10.1186/s12936-018-2182-z

Posner GH, D'Angelo J, O'Neill PM, Mercer A (2006). Anticancer activity of artemisinin-derived trioxanes. Expert Opinion on Therapeutic Patents. 16(12):1665-1672. https://doi.org/10.1517/13543776.16.12.1665

Price RN (2000). Artemisinin drugs: novel antimalarial agents. Expert Opinion on Investigational Drugs 9(8):1815-1827. https://doi.org/10.1517/13543784.9.8.1815

Qiang W, Cai W, Yang Q, Yang L, Dai Y, Zhao Z, ... Zhu X (2018). Artemisinin B improves learning and memory impairment in $\mathrm{AD}$ dementia mice by suppressing neuroinflammation. Neuroscience 395:1-12. https://doi.org/10.1016/j.neuroscience.2018.10.041

Qiu F, Wu S, Lu X, Zhang C, Li J, Gong M, Wang M (2018). Quality evaluation of the artemisinin-producing plants Artemisia annua L. based on simultaneous quantification of artemisinin and six synergistic components and hierarchical cluster analysis. Industrial Crops and Products 118:131-141. https://doi.org/10.1016/j.indcrop.2018.03.043

Rafika G, Zahia H, Nesma H (2018). Chemical composition and antibacterial activity of Artemisia campestris spp. glutinosa (J. Gay) Batt. and A. judaica spp. sahariensis (Chev.) species endemic to the Algerian Sahara. Journal of Essential Oil-Bearing Plants 21(3):779-788. https://doi.org/10.1080/0972060X.2018.1484819

Rahman SU, Khalid M, Kayani SI, Jan F, Ullah A, Tang K (2019). Biological activities artemisinins beyond anti-malarial: a review. Tropical Plant Biology. https://doi.org/10.1007/s12042-019-09228-0

Ram M, Jain DC, MishraH, Mandal S, Abdin MZ (2014). Recent advances to enhance yield of artemisinin: a novel antimalarial compound. Artemisia annua L. plants. Springer-Verlag, Berlin Heidelberg. http://dx.doi.org.10.1007/978-3-642-41027-7-11.

Ranjbar M, Naghavi MR, Alizadeh H (2020). Chemical composition of the essential oils of Artemisia species from Iran: a comparative study using multivariate statistical analysis. Journal of Essential Oil Research. https://doi.org/10.1080/10412905.2020.1750495

Rao BRR, Syamasundar KV, Patel RP (2014). Effects of method of distillation on the yield and chemical composition of Artemisia annua essential oil. Journal of Essential Oil Research 26(6):486-491. https://doi.org/10.1080/10412905.2014.949881

Rassias DJ, Weathers PJ (2019). Dried leaf Artemisia annua efficacy against non-small cell lung cancer. Phytomedicine 52:247-253. https://doi.org/10.1016/j.phymed.2018.09.167 
Rath K, Taxis K, Walz G, Gleiter CH, Li S-M, Heide L (2004). Pharmacokinetic study of artemisinin after oral intake of a traditional preparation of Artemisia annua L. (Annual Wormwood). The American Journal of Tropical Medicine and Hygiene 70(2):128-132. https://doi.org/10.4269/ajtmh.2004.70.128

Saleh MA, Belal MH, El-Baroty G (2006). Fungicidal activity of Artemisiaherba alba Asso (Asteraceae). Journal of Environmental Science and Health, Part B 41(3):237-244. https://doi.org/10.1080/03601230500354774

Salehi M, Karmizadeh G, Naghavi MR, Naghdi Badi H, Rashidi Monfared S (2018). Expression of artemisinin biosynthesis and trichome formation genes in five Artemisia species. Industrial Crops and Products 112:130-140. https://doi.org/10.1016/j.indcrop.2017.11.002

Sarder A, Pokharel YR (2018). Synthetic derivatives of artemisinin and cancer. International Journal of Medicine and Biomedical Sciences 1:54-58.

Sekiou O, Boumendjel M, Taibi F, Boumendjel A, Messarah M (2019). Mitigating effects of antioxidant properties of Artemisia herba alba aqueous extract on hyperlipidemia and oxidative damage in alloxan-induced diabetic rats. Archives of Physiology and Biochemistry 125(2):163-173. https://doi.org/10.1080/13813455.2018.1443470

Shahrajabian MH, Sun W, Cheng Q(2019a). Clinical aspects and health benefits of ginger (Zingiber officinale) in both traditional Chinese medicine and modern industry. Acta Agriculturae Scandinavica, Section B-Soil \& Plant Science 1-11. https://doi.org/10.1080/09064710.2019.1606930

Shahrajabian MH, Sun W, Cheng Q (2019b). A review of ginseng species in different regions as a multipurpose herb in traditional Chinese medicine, modern herbology and pharmacological science. Journal of Medicinal Plants Research 13(10):213-226.

Shahrajabian MH, Sun W, Cheng Q (2019c). Modern pharmacological actions of longan fruits and their usages in traditional herbal remedies. Journal of Medicinal Plants Studies 7(4):179-185.

Shahrajabian MH, Sun W, Cheng Q (2019d). DNA methylation as the most important content of epigenetics in traditional Chinese herbal medicine. Journal of Medicinal Plants Research 13(16):357-369. https://doi.org/10.5897/JMPR2019.6803

Shahrajabian MH, Sun W, Shen H, Cheng Q (2020a). Chinese herbal medicine for SARS and SARS-CoV-2 treatment and prevention, encouraging using herbal medicine for COVID-19 outbreak. Acta Agriculturae Scandinavica, Section B- Soil \& Plant Science. https://doi.org/10.1080/09064710.2020.1763448

Shahrajabian MH, Sun W, Cheng Q (2020b). Chinese star anise (Illicium verum) and pyrethrum (Chrysanthemum cinerariifolium) as natural alternatives for organic farming and health care- A review. Australian Journal of Crop Sciences 14(03):517-523. https://doi.org/10.21475/ajcs.20.14.03.p2209

Shahrajabian MH, Sun W, Cheng Q (2020c). Considering white gold, cotton for its fiber, seed oil, traditional and modern health benefits. Journal of Biological and Environmental Sciences 14(40):25-39.

Shahrajabian MH, Sun W, Cheng Q (2020d). Chinese onion, and shallot, originated in Asia, medicinal plants for healthy daily recipes. Notulae Scientia Biologicae 12(2):197-207. https://doi.org/10.15835/nsb12210725

Shatar S, Dung NX, Karashawa D (2003). Essential oil composition of some Mongolian Artemisia species. Journal of Essential Oil-Bearing Plants 6(3):203-206. https://doi.org/10.1080/0972-060X.2003.10643353

ShenQ, Yan T, Fu X, Tang K (2016). Transcriptional regulation of artemisinin biosynthesis in Artemisia annua L. Science Bulletin 61(1):18-25. https://doi.org/10.1007/s11434-015-0983-9

Shen Q, Zhang K, Liao Z, Wang S, Yan T, Shi P, ... Tang K (2018). The genome of Artemisia annua provides insight into the evolution of Asteraceae family and artemisinin biosynthesis. Molecular Plant 11:776-788. https://doi.org/10.1016/j.molp.2018.03.015

Shi C, Li H, Yang Y, Hou L (2015). Anti-inflammatory and immunoregulatory functions of artemisinin and its derivatives. Mediators of Inflammation 2015:435713. https://doi.org/10.1155/2015/435713

Shi Z, Chen Y, Lu C, Dong L-M, Lv J-W, Tuo Q-H, ... Liu X-M (2018). Resolving neuroinflammation, the therapeutic potential of the anti-malaria drug family of artemisinin. Pharmacological Research 136:172-180. https://doi.org/10.1016/j.phrs.2018.09.002

Song Z, Cheng K, Zhang L, Wang T (2017). Dietary supplementation of enzymatically treated Artemisia annua could alleviate the intestinal inflammatory response in heat-stressed broilers. Journal of Thermal Biology 69:184-190. https://doi.org/10.1016/j.jtherbio.2017.07.015

Stojanovic G, Palic R, Mitrovic J, Djokovic D (2000). Chemical composition and antimicrobial activity of the essential oil of Artemisia lobelii all. Journal of Essential Oil Research 12(5):621-624. https://doi.org/10.1080/10412905.2000.9712172 
Sulsen V, Frank FM, Cazorla SI, Anesini CA, Malchiodi EL, Fleixa B, ... Martino VS (2008). Trypanocidal and leishmanicidal activities of sesquiterpene lactones from Ambrosia tenuifolia Sprengel (Asteraceae). Antimicrobial Agents and Chemotherapy 52:2415-2419. https://doi.org/10.1128/AAC.01630-07

Sulsen V, Gutierrez Yappu D, Laurella L, Anesini C, Gimenez Turba A, Martino V, Muschietti L (2011). In vitro antiplasmodial activity of sesquiterpene lactones from Ambrosia tenuifolia. Evidence-Based Complementary and Alternative Medicine 2011:352938. https://doi.org/10.1155/2011/352938

Sun W, Shahrajabian MH, Cheng Q (2019a). The insight and survey on medicinal properties and nutritive components of shallot. Journal of Medicinal Plant Research 13(18):452-457. https://doi.org/10.5897/JMPR2019.6836

Sun W, Shahrajabian MH, Cheng Q (2019b). Anise (Pimpinella anisum 1.), a dominant spice and traditional medicinal herb for both food and medicinal purposes. Cogent Biology 5(1673688):1-25. https://doi.org/10.1080/23312025.2019.1673688

Sun W, Shahrajabian MH, Khoshkharam M, Cheng Q (2020a). Adaptation of acupuncture and traditional Chinese herbal medicines because of climate change. Journal of Stress Physiology and Biochemistry 16(1):85-90.

Sun W, Shahrajabian MH, Cheng Q (2020b). Pyrethrum an organic and natural pesticide. Journal of Biological and Environmental Sciences 14(40):41-44.

Suresh J, Mahesh NM, Ahuja J, Santilna KS (2011). Review on Artemisia nilagirica (Clarke) pamp. Journal of Biologically Active Products from Nature 1(2):97-104. https://doi.org/10.1080/22311866.2011.10719075

Tadayoni Z, Shafaroodi H, Asgarpanah J (2018). Analgesic and anti-inflammatory activities of the essential oil from Artemisia aucheri Boiss. Journal of Essential Oil-Bearing Plants 21(2):440-448. https://doi.org/10.1080/0972060X.2017.1396929

Taherkhani M (2015). Anti-cancer, cytotoxic activity, mutagenic and anti-mutagenic activities of Artemisia aucheri essential oil. Journal of Essential Oil-Bearing Plants 18(6):1329-1337. https://doi.org/10.1080/0972060X.2014.1000388

Tu Y (2016). Artemisinin-a gift from traditional Chinese medicine to the world (nobel lecture). Angewandte Chemie International Edition 55(35):10210-10226. https://doi.org/10.1002/anie.201601967

Usuda M, Endo T, Nagase H, Tomono K, Ueda H (2000). Interaction of antimalarial agent artemisinin with cyclodextrins. Drug Development and Industrial Pharmacy 26(6):613-619. https://doi.org/10.1081/DDC100101276

Vasylievna ZS, Erdemovna RT, Dorzhievna RL, Arnoldovich A-O, Long CS, Qingbo G, Qi ZF (2015). Comparative studies on composition of essential oil in three wormwoods (Artemisia L.) from Buryatia and Mongolia. Journal of Essential Oil-Bearing Plants 18(3):637-641. https://doi.org/10.1080/0972060X.2014.958547

Viljoen AM, Van Vuuren SF, Gwebu T, Demirci B, Baser KHC (2006). The geographical variation and antimicrobial activity of African wormwood (Artemisia afra Jacq.) essential oil. Journal of Essential Oil Research 18(1):19-25. https://doi.org/10.1080/10412905.2006.12067114

Wang Y, Liu J-K (2012). Improvement of the HLPC determination condition for artemisinin and its derivatives. Journal of Liquid Chromatography and Related Technologies 35(12):1712-1718. https://doi.org/10.1080/10826076.2011.621498

Wang B, Hou D, Liu Q, Wu T, Guo H, Zhang X, ... Shao C (2015). Artesunate sensitizes ovarian cancer cells to cisplatin by downregulating RAD51. Cancer Biology and Therapy 16(10):1548-1556. https://doi.org/10.1080/15384047.2015.1071738

Wang KS, Li J, Wang Z, Mi C, Ma J, Piao LX, ... Jin X (2017). Artemisinin inhibits inflammatory response via regulating NF- $\kappa \mathrm{B}$ and MAPK signaling pathways. Immunopharmacology and Immunotoxicology 39(1):28-36. https://doi.org/10.1080/08923973.2016.1267744

Weathers PJ, Elfawal MA, Towler MJ, Acquaah-Mensah GJ, Rich SM (2014). Pharmacokinetics of artemisinin delivered by oral consumption of Artemisia annua dried leaves in healthy vs. Plasmodiumchabaudi-infected mice. Journal of Ethnopharmacology 153:732-736. https://doi.org/10.1016/j.jep.2014.03.037

Wen L, LiuL, Wen L, Yu Y, Wei F (2018). Artesunate promotes G2/M cell cycle arrest in MCF7 breast cancer cells through ATM activation. Breast Cancer 25:681-686. https://doi.org/10.1007/s12282-018-0873-5

WidmerV, Handloser D, Reich E (2007). Quantitative HPTLC analysis of artemisinin in dried Artemisia annua L.: A practical approach. Journal of Liquid Chromatography and Related Technologies 30(15):2209-2219. https://doi.org/10.1080/108260707014551555 
Wojtkowiak-Giera A, Derda M, Kosik-Bogacka D, Kolasa-Wolosiuk A, Solarczyk P, Cholewinski M, ... Hadas E (2018). Influence of Artemisia annua L. on toll-like receptor expression in brain of mice infected with Acanthamoebasp. Experimental Parasitology 185:17-22. https://doi.org/10.1016/j.exppara.2018.01.008

Wojtkowiak-Giera A, Derda M, Kosik-Bogacka D, Kolasa-Wolosiuk A, Wandurska-Nowak E, Jagodzinski PP, Hadas E (2019). The modulatory effect of Artemisia annua L. on toll-like receptor expression in Acanthamoeba infected mouse lungs. Experimental Parasitology 199:24-29. https://doi.org/10.1016/j.exppara.2019.02.011

Wu Y, Tang W, Zuo J (2016). Development of artemisinin drugs in the treatment of autoimmune diseases. Science Bulletin 61(1):37-41. https://doi.org/10.1007/s11434-015-0975-9

Wu Y, Jiang X, Zhang L, Zhou Y (2017). Chemical composition and biological activities of volatile oils in different periods of growth of Artemisia annua L. from China. Journal of Essential Oil-Bearing Plants 20(5):1320-1330. https://doi.org/10.1080/0972060X.2017.1392899

Xiao SH, Xue J, Mei JY, Jiao PY (2012). Effectiveness of synthetic trioxolane OZ78 against Schistosoma japonicum in mice and rabbits. Parasitology Research 110(6):2307-2314. https://doi.org/10.1007/s00436-011-2765-X

Xiao L, Tan H, Zhang L (2016). Artemisia annua glandular secretory trichomes: the bio factory of antimalarial agent artemisinin. Science Bulletin 61(1):26-36. https://doi.org/10.1007/s11434-015-0980-z

Yan L, Xiong C, Xu P, Zhu J, Yang Z, Ren H, Luo Q (2019). Structural characterization and in vitro antitumor activity of A polysaccharide from Artemisia annua L. (Huang Huahao). Carbohydrate Polymers 213:361-369. https://doi.org/10.1016/j.carbpol.2019.02.081

Yao W, Wang F, Wang H (2016). Immunomodulation of artemisinin and its derivatives. Science Bulletin 61(18):13991406. https://doi.org/10.1007/s11434-016-1105-Z

Yao Y, Guo Q, Cao Y, Qiu Y, TanR, Yu Z, Zhou Y, Lu N (2018). Artemisinin derivatives inactivate cancer-associated fibroblasts through suppressin TGF- $\beta$ signaling in breast cancer. Journal of Experimental \& Clinical Cancer Research 37:282. https://doi.org/10.1186/s13046-018-0960-7

Yuan X, Li J, LiY, Deng Z, Zhou L, Long J, Tang Y, Zuo Z, Zhang Y, Xie H (2019). Artemisinin, a potential option to inhibit inflammation and angiogenesis in rosacea. Biomedicine and Pharmacotherapy 117:109181. https://doi.org/10.1016/j.biopha.2019.109181

Zeng Q-P, Zeng L-X, Lu W-J, Feng L-L, Yang R-Y, Qiu F (2012). Enhanced artemisinin production from engineered yeast precursors upon biotransformation. Biocatalysis and Biotransformation 30(2):190-202. https://doi.org/10.3109/10242422.2012.661723

Zeng H, Yuan L, Huang J (2018). Negative effects of artemisnin on phosphorus solubilizing bacteria in vitro. Ecotoxicology and Environmental Safety 158:108-113. https://doi.org/10.1016/j.ecoenv.2018.04.11

Zhang H, Zhang L, Hu X, Zhou Y, Ding C, Yang R, Wang X, Li D (2014). Optimization of ultrasound-assisted extraction of artemisinin from Artemisia annua L. by response surface methodology. Separation Science and Technology 49(5):673-681. https://doi.org/10.1080/01496395.2013.862554

Zhang H, Ji Y, Chen Q, Jiao X, Hou L, Zhu X, Zhang Z (2015). Enhancement of cytotoxicity of artemisinin toward cancer cells by transferring-mediated carbon nanotubes nanoparticles. Journal of Drug Targeting 23(6):552-567. https://doi.org/10.3109/1061186X.2015.1016437

Zhang Y, Xu G, Zhang S, Wang D, Prabha PS, Zuo Z (2018). Antitumor research on artemisinin and its bioactive derivatives. Natural Products and Bioprospecting. https://doi.org/10.1007/s13659-018-0162-1

Zhao X, Wang L, Zhang H, Zhang D, Zhang Z, Zhang J (2015). Protective effect of artemisinin on chronic alcohol induced-liver damage in mice. Environmental Toxicology and Pharmacology 52:221-226. https://doi.org/10.1016/j.etap.2017.04.008

Zhao D, Zhang J, Xu G, Wang Q (2017). Artesunate protects LPS-induced acute lung injury by inhibiting TLR4 expression and inducing Nrf2 activation. Inflammation 40:798-805. https://doi.org/10.1007/s10753-017-05246

Zheng W, Wang SY (2001). Antioxidant activity and phenolic compounds in selected herbs. J. Agric. Food Chemistry 49:5165-5170. https://doi.org/10.1021/jf010697n

Zhigzhitzhapova SV, Dylenova EP, Gulyaev SM, Randalova TE, Taraskin VV, Tykheev ZA, Radnaeva LD (2019). Composition and antioxidant activity of the essential oil of Artemisia annua L. Natural Product Research. http://doi.org/10.1080/14786419.2018.1548461

Zhu XX, Yang L, Li YJ, Zhang D, Chen Y, Kostecka P, Kmoniekova E, Zidek Z (2013). Effects of sesquiterpene, flavonoid and coumarin types of compounds from Artemisia annua L. on production of mediators of angiogenesis. Pharmacological Reports 65(2):410-420. https://doi.org/10.1016/S1734-1140(13)71016-8 
Zyad A, Tilaoui M, Jaafari A, Oukerrou MA, Mouse HA (2017). More insights into the pharmacological effects of artemisinin. Phytotherapy Research 1-14. https://doi.org/10.1002/ptr.5958

OPEN ACCESS

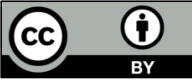

The journal offers free, immediate, and unrestricted access to peer-reviewed research and scholarly work. Users are allowed to read, download, copy, distribute, print, search, or link to the full texts of the articles, or use them for any other lawful purpose, without asking prior permission from the publisher or the author.

License - Articles published in Notulae Botanicae Horti Agrobotanici Cluj-Napoca are Open-Access, distributed under the terms and conditions of the Creative Commons Attribution (CC BY 4.0) License.

(c) Articles by the authors; UASVM, Cluj-Napoca, Romania. The journal allows the author(s) to hold the copyright/to retain publishing rights without restriction. 